\title{
DIVERSIFIKASI HASIL PERTANIAN TERINTEGRASI DAN PENDAPATAN PETANI PETERNAK DI DESA KERTA KECAMATAN PAYANGAN KABUPATEN GIANYAR
}

\author{
Study of The Diversification Potential Of Integrated Agricultural Yields \\ Supporting Food Security In Kerta Village, Payangan Sub-District Of \\ Gianyar Regency
}

\section{Ni Putu Widhyawaty}

\begin{abstract}
Program Studi Pertanian Lahan Kering, Fakultas Pertanian Universitas Udayana, Bali, Indonesia
\end{abstract}
Email : putu_widhya@yahoo.co.id

\begin{abstract}
S
The successful diversification of product yields is the main characteristic of integrated agriculture. Diversified farming in order to obtain optimal results requires management that is more comprehensive. The purpose of this study was to find out the main and side yields, the quality of the product, the level of food diversification, and the income level of simantri and non-simantri farmers in Kerta Village, Payangan Sub-District, Gianyar Regency. The study was designed as a quantitative descriptive study through survey activities in Kerta Village, Payangan Sub-district, Gianyar Regency for one year by taking samples of farmers who implemented simantri and non-simantri. The main products of farmers in Kerta Village are citrus fruits, guava, mangosteen, durian, heliconia, and banana leaves and livestock products including meat, calves, and chicken eggs. The by-products are biogas, biourine and compost with better quality because they are carried out according to the procedure so that the amount of pathogenic bacteria can be reduced in number to reduce water, air and soil pollution. Diversification of integrated agricultural products in Kerta Village is carried out by processing manure into biogas and bio urine that provide economic benefits to farmers, especially as production facilities in the form of compost and liquid fertilizer used by farmers to improve soil fertility. In general, the income of farmers in integrated farming systems (simantri) in Kerta village is increasing, because in addition to obtaining yields from agriculture and plantations, it is also from livestock, which actually increases their income from the results of animal husbandry processing.
\end{abstract}

Keywords: Diversification, Revenue, Simantri, Non Simantri.

\begin{abstract}
ABSTRAK
Diversifikasi hasil produk yang sukses adalah karakteristik utama pertanian terintegrasi. Pertanian yang beragam untuk mendapatkan hasil yang optimal membutuhkan manajemen yang lebih komprehensif. Tujuan dari penelitian ini adalah untuk mengetahui hasil utama dan samping, kualitas produk, tingkat diversifikasi pangan, dan tingkat pendapatan petani simantri dan non-simantri di Desa Kerta, Kecamatan Payangan, Kabupaten Gianyar. Penelitian ini dirancang sebagai penelitian deskriptif kuantitatif melalui kegiatan survei di Desa Kerta, Kecamatan Payangan, Kabupaten Gianyar selama satu tahun dengan mengambil sampel petani yang menerapkan simantri dan non-simantri. Produk utama petani di Desa Kerta adalah buah jeruk, jambu biji, manggis, durian, heliconia, dan daun pisang serta produk ternak termasuk daging, anak sapi, dan telur ayam. Produk sampingnya adalah biogas, biourine dan kompos dengan kualitas yang lebih baik karena dilakukan sesuai prosedur sehingga jumlah bakteri patogen dapat dikurangi jumlahnya untuk mengurangi polusi air, udara dan tanah. Diversifikasi produk pertanian terintegrasi di Desa Kerta dilakukan dengan mengolah kotoran ternak menjadi biogas dan biogas yang memberikan manfaat ekonomi bagi petani, terutama sebagai fasilitas produksi dalam bentuk kompos dan pupuk cair yang digunakan petani untuk meningkatkan kesuburan tanah. Secara umum, pendapatan petani dalam sistem pertanian terpadu (simantri) di desa Kerta meningkat, karena selain mendapatkan hasil dari pertanian dan perkebunan, juga dari ternak, yang sebenarnya meningkatkan pendapatan mereka dari hasil pengolahan peternakan.
\end{abstract}

Kata kunci: Diversifikasi, Penghasilan, Simantri, Non Simantri 


\section{PENDAHULUAN}

Sistem Pertanian Terintegrasi atau lebih dikenal dengan Simantri telah menjadi model pembangunan pertanian daerah di Provinsi Bali. Program Simantri didukung sepenuhnya oleh Pimpinan Daerah melalui visi dan kebijakan perencanaan program pembangunan strategis daerah untuk "Bali Mandara" (Bali Aman Damai dan Sejahtera). Simantri pada dasarnya adalah integrasi vertikal dan horizontal kegiatan usahatani di tingkat lokal, mulai dari proses perencanaan, perumusan kebijakan hingga implementasi. Diversifikasi usahatani juga dibangun untuk mendukung kelembagaan Simantri. Program Simantri telah dilaksanakan pada tahun 2008-2013 dan kemudian dilanjutkan 2013-2018 (Biro Humas, Pemerintah Provinsi Bali, 2011).

Usaha tani terdiversifikasi agar mendapat hasil optimal perlu dilakukan pengelolaan atau manajemen terhadap faktor-faktor produksi yang berpengaruh dengan berbagai karakter keterbatasan masing-masing melalui penyusunan kombinasi dari masing masing faktor produksi. Penyusunan dari berbagai faktor produksi tersebut akan menghasilkan berbagai kemungkinan/alternatif kombinasi yang dapat dilaksanakan. Keseluruhan kombinasi tersebut, salah satunya tentu merupakan alternatif terbaik yang akan memberikan hasil optimal. Memperhatikan kondisi tersebut maka upaya pemberdayaan perDesaan menjadi mutlak untuk dilakukan antara lain melalui Program Sistem Pertanian Terintegrasi (Simantri). Direktorat Jenderal Peternakan (2010) menyebutkan bahwa model integrasi tanaman ternak yang dikembangkan di lokasi beberapa daerah dan negara berorientasi pada konsep "zero waste production system" yaitu seluruh limbah dari ternak dan tanaman didaur ulang dan dimanfaatkan kembali ke dalam siklus produksi. Komponen usahatani dalam model ini meliputi usaha ternak sapi potong, tanaman pangan (padi atau jagung), hortikultura (sayuran), perkebunan, (tebu) dan perikanan (lele, gurami, nila). Limbah ternak (kotoran sapi) diproses menjadi kompos dan pupuk organik granuler, biourine serta biogas; limbah pertanian (jerami padi, batang dan daun jagung, pucuk tebu, jerami kedelai dan kacang tanah) diproses menjadi pakan. Gas-bio dimanfaatkan untuk keperluan memasak, sedangkan limbah biogas (sludge) yang berupa padatan dimanfaatkan menjadi kompos dan bahan campuran pakan sapi dan ikan, dan yang berupa cairan (biourine) dimanfaatkan menjadi pupuk cair untuk tanaman sayuran dan ikan.

Kecamatan Payangan merupakan daerah agropolitan yang dikembangkan oleh Pengkab Gianyar. Kawasan ini merupakan daerah sentra pertanian tanaman campuran yang terintegrasi dengan ternak sapi Bali. Di kawasan ini sejak tahun 2007 s/d 2009 telah dikembangkan program Prima Tani dengan mengoptimalisasikan pengembangan agroindustri pedesaan dan sistem usaha tani intensifikasi dan diversifikasi dengan sasaran meningkatkan nilai tambah produk dan tingkat pendapatan petani. Lokasi pengembangan prima tani difokuskan di Desa Kertha yang memiliki luas wilayah 1.442 hektar (Kariada et al., 2008).

Menurut Januwiata et al (2013) Desa Kertha memiliki keunggulan dibidang pertanian dalam arti luas terutama pada pertanian tanaman pangan yang didukung 5 subak dengan luasan sawah 153 hektar dan 5 subak abian yang mengembangkan beberapa komoditi diantaranya tanaman hortikultura, tanaman perkebunan,tanaman pangan, tanaman kehutanan dan tanaman bunga potong yang saat ini berkembang pesat termasuk tanaman buah-buahan seperti jeruk. Potensi peternakan Desa Kertha saat ini mengembangkan jenis ternak sapi, babi dan ayam dengan masingmasing kepala keluarga memelihara 2 ekor sapi.

Program simantri yang telah berjalan sekitar 6 tahun telah sepenuhnya diserahkan kepada petanipeternak anggota Gapoktan Simantri. Fakta di lapangan menunjukkan masih banyak ditemui masalah dalam penerapan program ini salah satunya pengolahan limbah ternak sapi menjadi pupuk padat dan cair yang belum optimal sampai pada kegagalan Gapoktan simantri dalam menjaga eksistensinya. Bercermin dari permasalahan penerapan program ini dilapangan, menarik kiranya bagi penulis untuk mengamati lebih jauh bagaimana tingkat penerapan Simantri oleh petani-peternak jika dilihat dari kualitas keragaman produk yang dihasilkan dari program simantri dan non simantri mengingat adopsi inovasi dalam program simantri bersifat intervensi dari pemerintah Propinsi Bali selaku pengelola kepada anggota Gapoktan Simantri sebagai pelaksana program ini.

Penelitian ini bertujuan untuk mengetahui hasil utama dan sampingan, kualitas hasil produk, tingkat diversifikasi pangan masing-masing produk yang dihasilkan serta tingkat pendapatan petani pola simantri dan non simantri di Desa Kerta Kecamatan Payangan Kabupaten Gianyar.

\section{BAHAN DAN METODE}

Penelitian ini dilakukan di Desa Kerta Kecamatan Payangan Kabupaten Gianyar dari bulan Januari sampai dengan Desember 2016 menggunakan metode survei. Variabel pengamatan pada penelitian ini adalah diversifikasi hasil pertanian terintegrasi meliputi hasil utama dan pendapatan petani. Data diperoleh dari petani peternak yang 
termasuk dalam kelompok non simantri sebanyak 15 kelompok dalam gapoktan dan 2 kelompok petani peternak yang tergolong simantri. Data pengeluaran seperti biaya investasi pupuk, bibit serta hasil penjualan dipergunakan untuk menghitung pendapatan dari petani peternak. Data dianasis secara secara diskriptif dan mempergunakan distrubusi frekuensi.

\section{HASIL DAN PEMBAHASAN}

Simantri di Desa Kerta Kecamatan Payangan Kabupaten Gianyar menghasilkan tanaman utama berupa buah-buahan seperti: jeruk 40,9\%, jambu, manggis, dan durian sebanyak $59,1 \%$, padi $27,3 \%$, Heliconia 4,5\%, dan pisang sebanyak $9,1 \%$. Sedangkan, hasil pertanian sampingannya adalah kubis, pepaya, dan kelapa. Jeruk menjadi komponen utama terbesar yang dihasilkan petani peternak karena tanaman jeruk sangat responsive terhadap penggunaan pupuk organik yang berasal dari kotoran ternak. Kebanyakan petani simantri dan non Simantri saat ini memupuk tanaman jeruknya dengan kotoran ternak secara langsung tanpa terlebih dahulu dilakukan pengolahan. Pupuk dari limbah biogas (Slurry) juga digunakan langsung tanpa penambahan fermentor sehingga belum berperan optimal sebagai pupuk organik bioslurry. Kualitas Slurry lebih rendah dari bioslurry.

Petani peternak selain memelihara ternak sapi juga memelihara ternak lainnya seperti memelihara babi sebanyak $29 \%$ dan ayam buras sebanyak 25,9\%. Jumlah (populasi) ternak sapi yang dipelihara adalah sebanyak 70 ekor. Seorang petani memelihara ternak sapi 2 sampai 5 ekor. Produksi pupuk kotoran ternak yang dijual masih rendah karena kebanyakan kotoran sapi dialirkan langsung ke tanaman pertanian atau perkebunan. Pupuk kandang yang dihasilkan oleh petani peternak semuannya berasal dari kandang petani peternak sendiri, belum ada petani peternak yang membuat pupuk kandang dengan mendatangkan atau membeli kotoran ternak dari tempat lain.

\section{Diversifikasi Produk Sistem Pertanian Terintegrasi Mendukung Ketahanan Pangan}

Diversifikasi merupakan upaya penganekaragaman kegiatan atau produk sehingga terjadi keserasian. Di sektor pertanian diversifikasi meliputi diversifikasi konsumsi dan diversifikasi produksi. Diversifikasi konsumsi merupakan upaya penganekaragaman pola konsumsi masyarakat, sedangkan diversifikasi produksi merupakan upaya penganekaragaman kegiatan usahatani dan hasil-hasil produksi pertanian. Secara garis besar diversifikasi di bidang produksi terbagi dalam diversifikasi horizontal dan diversifikasi vertikal (Afiff, 1988). Diversifikasi horizontal merupakan upaya pemanfaatan sumberdaya (lahan) melalui penganekaragaman usahatani (komoditas) dalam rangka mewujudkan keserasian pengembangan komoditas dan wilayah. Pada tingkat mikro pemanfaatan sumberdaya lahan antara lain dilakukan melalui diversifikasi usahatani yaitu pergiliran tanaman. Diversifikasi vertikal merupakan upaya pemanfaatan atau hasil pertanian (komoditas) melalui penganekaragaman produk pertanian sehingga dapat dihasilkan nilai tambah sebesar-besarnya melalui perluasan pasar dan efisiensi.

Fokus pembangunan pertanian di Provinsi Bali harus diarahkan untuk memberdayakan sektor pasca panen, pengolahan dan pemasaran hasil pertanian yang dari berbagai penelitian banyak meningkatkan nilai tambah, baik nilai tambah ekonomi (peningkatan pendapatan) maupun nilai tambah sosial (peningkatan dan penciptaan lapangan kerja). Pembangunan pertanian di Provinsi Bali ke depan tidak hanya menghasilkan produk segar, namun perlu diarahkan untuk diolah, untuk konsumsi maupun dijual sebagai produk komersial untuk meningkatkan taraf hidup dan kesejahteraan.

Potensi Diversifikasi Produk Pangan Olahan Lokal Hasil Penelitian menunjukkan bahwa sebaran produk pangan olahan sangat terkait erat dengan potensi ketersediaan bahan baku utama (pangan lokal). Bahan baku utama adalah bahan pembuatan produk olahan berasal minimal $25 \%$ dari produk pertanian, sesuai dengan salah satu pengertian agroindustri menurut Soekartawi (2000), dalam hal ini produk pertanian yang dimaksud adalah pangan lokal (tempat produk dibuat) yang merupakan bagian terbesar dari keseluruhan bahan baku pengolahan.

Kebiasaan memanfaatkan potensi lokal perlu terus digalakkan agar masyarakat mengurangi kecenderungan untuk hidup konsumtif, dengan kecenderungan hidup produktif. Kandungan gizi utama yang terkandung dalam produk pangan olahan adalah karbohidrat protein, lemak, vitamin dan mineral. Potensi ini dapat dikembangkan dalam upaya penanggulangan masalah gizi utama di Indonesia saat ini, termasuk Provinsi Bali yaitu kekurangan energi dan protein.

Masalah utama dalam ketahanan pangan adalah kurang pengetahuan masyarakat terhadap sumber energi dan zat gizi dan tersedianya beragam pilihan makanan siap konsumsi di tingkat individu. Dengan pengembangan produk pangan olahan ini, maka di kabupaten/kota yang belum mengenal produk pangan segar maupun olahan. Pengenalan dan promosi dilakukan secara terus menerus, baik melalui penyuluhan, pelatihan maupun pendampingan maka secara pelahanlahan masyarakat akan sadar akan potensi pangan lokal yang tersedia untuk memenuhi kebutuhan 
gizi agar hidup sehat tanpa harus mengeluarkan dana yang terlalu tinggi, sehingga kesadaran pangan gizi akan berdampak kepada kemandirian pangan, dan pada akhirnya akan menunjang ketahanan pangan berkelanjutan (sustainable food security). Produk pangan olahan lokal Desa Kerta sebagian besar sesungguhnya dapat dipromosikan sebagai industri rumah tangga, maupun untuk konsumsi rumah tangga dalam upaya perbaikan pola konsumsi pangan untuk penanggulangan masalah gizi. Potensi tersebut jika dikembangkan akan meningkatkan perekonomian desa, masyarakat tidak kekurangan gizi dan sektor pertanian yang menjadi pendukung penyedia bahan baku utama akan ikut terkena imbas positif.

Desa-desa di Provinsi Bali yang berbasis pertanian perlu dikembangkan seperti di Desa Kerta sebagai sentra industri pengolahan pangan (agroindustri, termasuk produk sampingannya) dan mampu mencukupi kebutuhan pangannya sehari-hari, tanpa harus konsumtif (mengeluarkan banyak uang untuk pangan). Tidak hanya swasembada, namun harus lebih diarahkan upaya kemandirian pangan. Kegiatan-kegiatan penelitian, pengabdian masyarakat, kuliah kerja nyata dan jalinan kerjasama kemitraan dengan stakeholders, perlu terus dikembangkan agar desa terus berkembang menjadi sentra agroindustri dan sentra produksi pangan segar dan olahan. Jika desa tersebut berkembang maka akan menghasilkan produk yang dapat dijual ke kota, sehingga arus bergerak dari desa ke kota, sebaliknya arus modal bergerak dari kota ke desa. Perputaran yang makin lancar dan cepat secara otomatis akan meningkatkan kesejahteraan masyarakat dan terhindar dari masalah kerawanan pangan.

Teknologi tepat guna, cara pengolahan, pengetahuan bahan baku, kandungan gizi produk, perlu terus disosialisasikan, dilatihkan dan dipraktekkan kepada kelompok tani di Desa Kerta agar pengetahuan dan keterampilan anggotanya terus bertambah. Dengan bertambahnya pengetahuan dan keterampilan, maka akan memotivasi untuk mengolah bahan mentah menjadi makanan siap saji, produk industri rumah tangga dalam upaya perbaikan gizi maupun peningkatan pendapatan keluarga. Pangan olahan jika banyak dijumpai di desa, maka akan banyak tersedia pilihan untuk dikonsumsi keluarga. Ketika pangan olahan banyak alternatif produknya, maka akan dibutuhkan banyak pula bahan baku untuk memenuhi kebutuhan pengolahan tersebut sehingga akan mendorong produktivitas di sektor hulu (on farm) (Sudaryanto, 2002).

Pengembangan diversifikasi pangan olahan lokal Bali khususnya Desa Kerta juga dapat dikembangkan melalui program aksi desa mandiri pangan yang dicanangkan oleh Badan Ketahanan Pangan Provinsi Bali. Desa Mandiri Pangan adalah desa yang masyarakatnya mempunyai kemampuan untuk mewujudkan ketahanan pangan dan gizi melalui pengembangan subsistem ketersediaan, subsistem distribusi dan subsistem konsumsi dengan memanfaatkan sumberdaya setempat secara berkelanjutan. Pengembangan desa mandiri pangan bertujuan untuk meningkatkan kemandirian pangan, meningkatkan peran dan fungsi kelembagaan masyarakat desa, mengembangkan sistem ketahanan pangan masyarakat desa, meningkatkan pendapatan masyarakat dan meningkatkan aksesibilitas masyarakat, dengan sasaran utama rumah tangga miskin di Desa Rawan Pangan. Kelompok tani yang mayoritas ibu rumah tangga dan remaja putri perlu lebih banyak dilibatkan dalam pengolahan pangan dalam upaya menunjang ketersedian pangan untuk dikonsumsi yang beragam, peningkatan ekonomi keluarga melalui usaha home industri.

\section{Pendapatan Petani Pada Sistem Pertanian Terintegrasi}

Pendapatan dalam penelitian ini dinilai dengan membandingkan pendapatan dari kegiatan mengintegrasikan ketiga unit usaha Simantri yang dilakukan responden dengan pendapatan sebelum mereka mengikuti program ini. Pengklarifikasian responden didasarkan pada seberapa besar (persentase) peningkatan pendapatan yang mereka peroleh setelah mengikuti Simantri.

Berdasarkan hasil penelitian yang diperoleh menunjukkan bahwa program simantri terbukti telah mampu meningkatkan pendapatan petani di Desa Kerta disebabkan oleh karena mereka mampu memaksimalkan produksi pupuk kompos dari ternak sapi yang ada. Selain itu kelompok tani di Desa Kerta juga terbukti mampu mendiversifikasikan usahanya melalui pembentukan unit-unit usaha baru yang berbasis pada potensi lokal sesuai dengan lokasi simantri itu berada. Berdasarkan hasil penelitian, peningkatan pendapatan yang diperoleh oleh para responden dapat dilihat pada Tabel 1 . 
Tabel 1. Pendapatan Petani Peternak Non Simantri Sub Sektor Pertanian, Perkebunan, dan Peternakan Per tahun

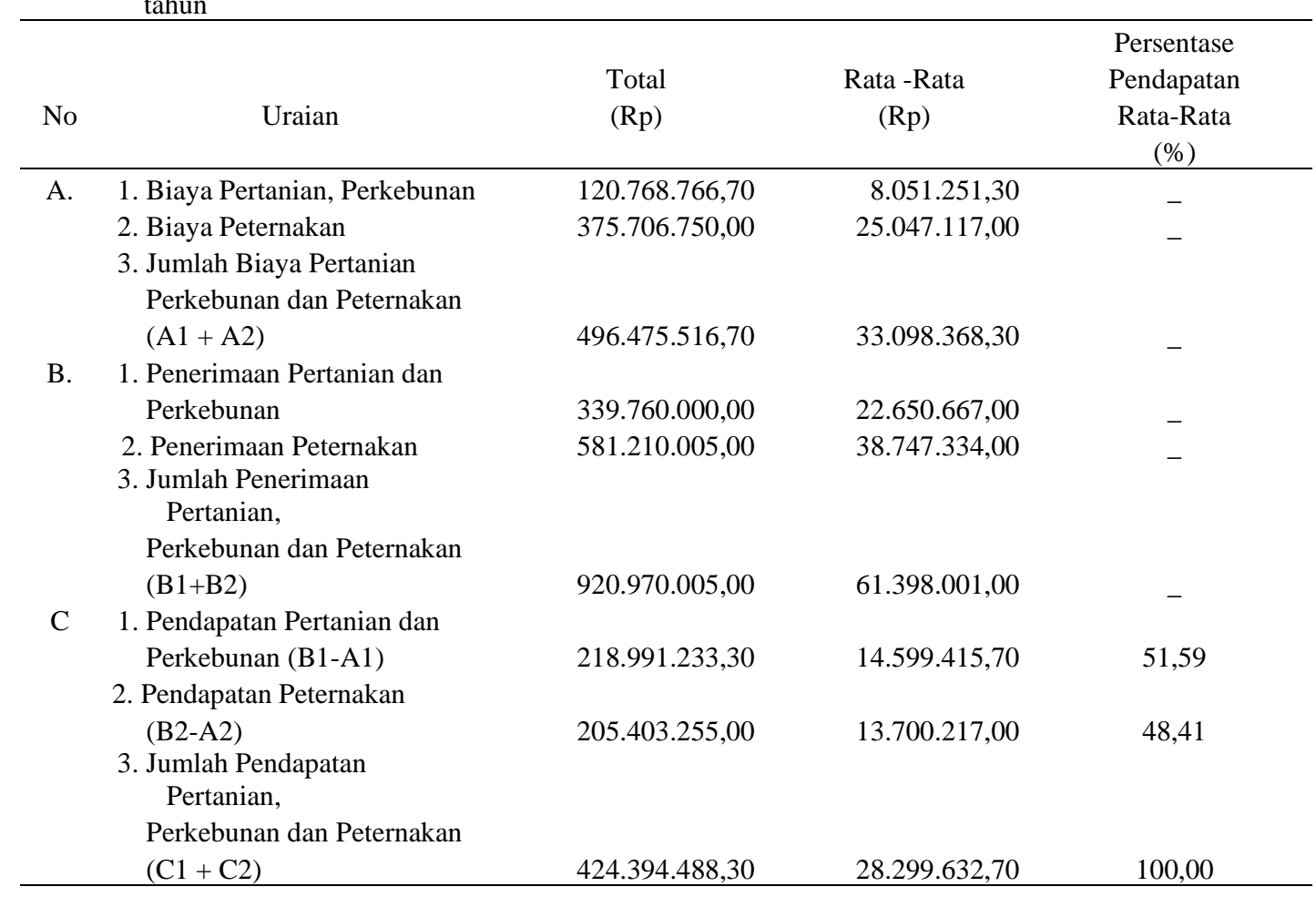

Tabel 2. Pendapatan Petani Peternak Simantri Sub Sektor Pertanian, Perkebunan, dan Peternakan Per tahun

\begin{tabular}{|c|c|c|c|c|}
\hline No & Uraians & $\begin{array}{l}\text { Total } \\
(\mathrm{Rp})\end{array}$ & $\begin{array}{l}\text { Rata -Rata } \\
\quad(\mathrm{Rp})\end{array}$ & $\begin{array}{c}\text { Persentase } \\
\text { Pendapatan } \\
\text { Rata-Rata } \\
(\%)\end{array}$ \\
\hline \multirow[t]{5}{*}{ A. } & 1. Biaya Pertanian, Perkebunan & $37.627 .916,67$ & $18.813 .959,00$ & _- \\
\hline & 2. Biaya Peternakan & $37.018 .000,00$ & $18.509 .000,00$ & _ \\
\hline & 3. Jumlah Biaya Pertanian & & & \\
\hline & Perkebunan dan Peternakan & & & \\
\hline & $(\mathrm{A} 1+\mathrm{A} 2)$ & 74.645.916,67 & $37.322 .959,00$ & - \\
\hline \multirow[t]{5}{*}{ B. } & 1. Penerimaan Pertanian dan & & & \\
\hline & Perkebunan & $60.000 .000,00$ & $30.000 .000,00$ & - \\
\hline & 2. Penerimaan Peternakan & $93.600 .000,00$ & $46.800 .000,00$ & _ \\
\hline & $\begin{array}{l}\text { 3. Jumlah Penerimaan Pertanian, } \\
\text { Perkebunan dan Peternakan }\end{array}$ & & & \\
\hline & $(\mathrm{B} 1+\mathrm{B} 2)$ & $118.600 .000,00$ & $59.300 .000,00$ & - \\
\hline \multirow[t]{7}{*}{$\mathrm{C}$} & 1. Pendapatan Pertanian dan & & & \\
\hline & Perkebunan (B1-A1) & $22.372 .083,33$ & $11.186 .041,00$ & 28,34 \\
\hline & 2. Pendapatan Peternakan & & & \\
\hline & (B2-A2) & $56.582 .000,00$ & $28.291 .000,00$ & 71,66 \\
\hline & 3. Jumlah Pendapatan Pertanian, & & & \\
\hline & Perkebunan dan Peternakan & & & \\
\hline & $(\mathrm{C} 1+\mathrm{C} 2)$ & $78.954 .083,33$ & $39.477 .041,00$ & 100,00 \\
\hline
\end{tabular}


Sesuai Tabel 1 rata-rata pendapatan petani peternak non simantri sebesar Rp. 28.299.632,70 pertahun. Adapun kontribusi pendapatan disumbangkan oleh sub sektor pertanian dan perkebunan sebesar $51,59 \%$ dan sub sektor peternakan sebesar $48,41 \%$. Ini berarti pada petani peternak non simantri sumbangan pendapatan berasal dari sektor pertanian dan perkebunan lebih banyak daripada sub sektor peternakan. Rata-rata pendapatan petani peternak Simantri terlihat pada Tabel 2 sebesar Rp. 39.477.041,00 pertahun. Adapun kontribusi pendapatan oleh sub sektor peternakan sebesar $71,66 \%$, dan sub sektor pertanian sektor perkebunan sebesar $28,34 \%$. Ini berarti pada petani peternak Simantri sumbangan pendapatan dari sub sektor peternakan lebih besar daripada sub sektor pertanian dan perkebunan.

\section{SIMPULAN}

Berdasarkan penelitian tersebut dapat disimpulkan bahwa: (1) Hasil Utama petani-peternak di Desa Kerta adalah tanaman buah-buahan jeruk, jambu, manggis, durian, Heliconia, dan daun pisang serta hasil peternakan meliputi daging, anak sapi (pedet) dan telur ayam ras. Hasil sampingannya adalah biogas, biourine dan pupuk kompos; (2) Kualitas Produk pupuk kompos Simantri Lebih baik daripada non Simantri; (3) Keberagaman produk yang dihasilkan dalam pola Simantri lebih beragam dibandingkan dengan non Simantri; (4) Rata-rata pendapatan petani-peternak Simantri di Desa Kerta Kecamatan Payangan Kabupaten Gianyar sebesar Rp. 39.477.041,00 pertahun lebih tinggi dari pendapatan petani-peternak non Simantri sebesar Rp. 28.299.632,70 pertahun. Pendapatan Simantri didominasi oleh sektor peternakan sedangkan non Simantri di dominasi sektor Pertanian dan perkebunan.

\section{DAFTAR PUSTAKA}

Afif. S., 1988. The Role of Agriculture in the Changing Structure of the Indonesian Economy. Institut Pengembangan Manajemen Indonesia.

Biro Humas Pemerintah Provinsi Bali, 2011. Gubernur Serahkan Hadiah Simantri 2010. Available from : URL : http:/www.birohumas.baliprov.go.id.ht $\mathrm{m}$.

Direktorat Jenderal Peternakan. 2009. Kebijakan Pengembangan Sapi Potong di Indonesia. Prosiding Workshop Nasional Dinamika dan Keragaan Sistem Integrasi Ternak - Tanaman: Padi, Sawit, Kakao. (In Press). Pusat Penelitian dan Pengembangan Peternakan, Bogor.
Kariada, I.K., I.B. Aribawa, N.Dwijana, N.Sumawa, dan M.A.Widyaningsih, 2008. Laporan Akhir Prima Tani Gianyar.BPTP Bali.

Soekartawi. 1988. Prinsip Dasar Komunikasi Pertanian. Universitas Indonesia, Jakarta.

Sudaryanto, T. dan Rusastra, I.W. (2002). Kebijaksanaan Strategis dalam Mendukung Kebijaksanaan Ketahanan Pangan Berwawasan Agribisnis. Monograph Series No.22 Pusat Penelitian dan Pengembangan Sosial Ekonomi Pertanian, Badan Penelitian dan Pengembangan Pertanian. 